\title{
Correction to: Higher Education in Market-Oriented Socialist Vietnam
}

\author{
Phan Le Ha and Doan Ba Ngoc
}

Correction to:

Phan, L. H and Doan, B. N (eds.),

Higher Education in Market-Oriented Socialist Vietnam, International and Development Education, https://doi.org/10.1007/978-3-030-46912-2

The original version of this book was inadvertently published with an error in the author's family name in the citation and running head. This has been corrected. The corrections to the book have been updated with the changes.

The updated version of the book can be found at https://doi.org/10.1007/978-3-030-46912-2

(C) The Author(s) 2020 